\title{
Rheumatology in art
}

\section{Extreme exorotation of a foot in a painting by Dirk Bouts (ca 1464)}

Dirk Bouts, born about 1410 in Haarlem, moved to Louvain (Belgium) before 1448, where he died in 1475. His painting "Ecce Agnus Dei", in which John the Baptist recognises Christ as the Lamb of God, is dated 1464. ${ }^{1}$ The description in the catalogue of the Leuven exhibition ${ }^{2}$ focuses on the many symbols in this picture (figs 1A and B):

Christ stands bareheaded on poor soil of sand and stones. The ascetic life leads him to a higher beauty, symbolised by the presence of gems on the banks and in the river. Lying in the water they represent the purifying power of the water. In contrast, St John and the donor are situated in luxuriant pastures.

Both riverbanks are optically connected by the tree of life. In the same way as the water of the baptism saves mankind from original sin, the leaves from the tree of life bring healing. Therefore St John not only points to Christ, but also to the tree of life and the water of life.

This concept of the significance of symbols in the painting is supported by the results of technical investigations. These show that Bouts made various attempts to paint the tree in exactly the right place. At first it occupied a position more to the left. It was then moved more centrally. Finally, the painter changed its location in such a way that it would do full justice to St John's gesture. ${ }^{3}$

In view of these detailed analyses it is surprising that the author does not refer to the unusual positioning of Jesus's right foot as a symbol. He does mention it in the same publication, ${ }^{3}$ but without comment. This right foot is shown in extreme exorotation and placed to the left of the left foot. In this position no special effort is necessary to make a half turn on a narrow path or to take the narrow way between the strewn pebbles and avoid risking stubbing his foot on imminent rock. This readily leads to the possibility of a symbolic meaning: it reminds the spectator of The Entrance into the Kingdom of Heaven (St Matthew 7, 13 and 14):

${ }^{13}$ Enter ye in at the strait gate: for wide is the gate, and broad is the way, that leadeth to destruction, and many there be which go in thereat.

${ }^{14}$ Because strait is the gate, and narrow is the way, which leadeth unto life, and few there be that find it.

Another special feature of this portrayal of the foot in this position is its uniqueness. Perusal of the relevant literature has failed to find another example, with one exception. ${ }^{4}$ This exception is a painting, with shows six men around $\mathrm{St}$ John, but in view of many, often minute details, it can be considered a close copy (fig 2). The number of pebbles in front of the feet of Christ, their sizes, and their positions are almost indistinguishable (compare figs $1 \mathrm{~B}$ and $2 \mathrm{~B}$ ), as are the shapes of the twigs and of the leaves of the trees. The difference in the number of accompanying figures in the second painting could well demonstrate different numbers of sponsors. The painter is unknown, but it is reasonable to think that it was Albrecht, the younger son of Bouts, who was the more successful of the two brothers. Bouts's testament stipulates that both his sons-Dirk and Albrechtshould inherit his painter's equipment and his unfinished pictures. There is no reason to doubt that this inheritance also included drawings of models, which explains the many imitations. Albrecht was born between 1453 and 1455 and died before 1549 .

In the catalogue mentioned above, Hélène Mund devotes a separate article to the subject of copying. "The extreme similarity of the compositions (subject, format, colours) does suppose that not only mechanical means of transfer have been used, but that without doubt the copier had the model before him." She also mentions the possible use of a perforated reproduction of the design ("calque perforé"). The copier could also have used a model, an example, in the form of a puppet or dummy, often with jointed limbs. In the local Flemish language this was called a "little man", a "mannekijn".

The mannequin as a live model was first mentioned in 1858, when the English designer Charles Frederick Worth opened his fashion house in Paris. The model's job was to show off the clothes as closely as possible to as large an audience as possible. The best way to effect this was to walk along a track on a raised platform flanked by the audience. At the end of this catwalk, in order to go back again, it is necessary to make a $180^{\circ}$ turn. One of the ways to achieve this is to place the feet in exactly the way as painted by Bouts. This lends further support to the thesis that Bouts's unusual positioning of the feet was not accidental, but that it has a symbolic meaning.

The author gratefully acknowledges the editorial assistance of Mrs A-M Caulkin. Professor Bloem, radiologist at the Leiden University Medical Centre, suggested the idea of the catwalk.

14 Vondellaan, $N L-2111 \mathrm{CN}$,

W HIJMANS

Aerdenhout, The Netherlands

whijmans@planet.nl

1 Bouts D. Ecce Agnus Dei (panel $53.8 \times 41.2 \mathrm{~cm}$ ). München: Bayerische Staatsgemäldesammlungen, Alte Pinakothek, inv. nr. 15192

2 Smeyers M, ed. Catalogue of the Dirk Bouts exhibition. Leuven, 1998. (ISBN 90-429-0661-8.)

3 Smeyers M. Dirk Bouts, Schilder van de stilte (painter of silence). Leuven: Davidsfonds, 1998. (ISBN 90-6152-606-6.)

4 After Bouts D. St fohn the Baptist recognises Christ on the bank of the river fordan (panel $73 \times 56 \mathrm{~cm}$ ). Berlin: Staatliche Museen Preussischer Kulturbesitz, Gemäldegalerie, inv. nr. 533c.

5 Mund H. La copie chez les Primitifs flamands et Dirk Bouts. See ref 2, pp 23146. 


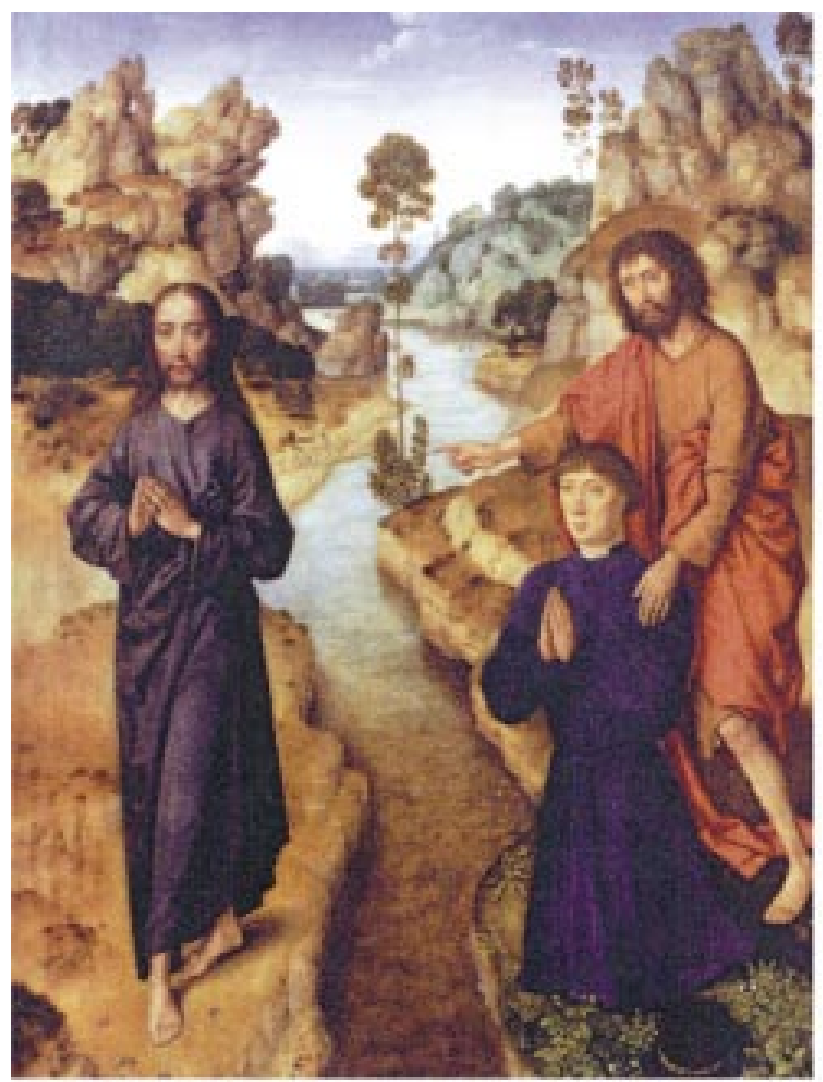

fig $1 \mathrm{~A}$

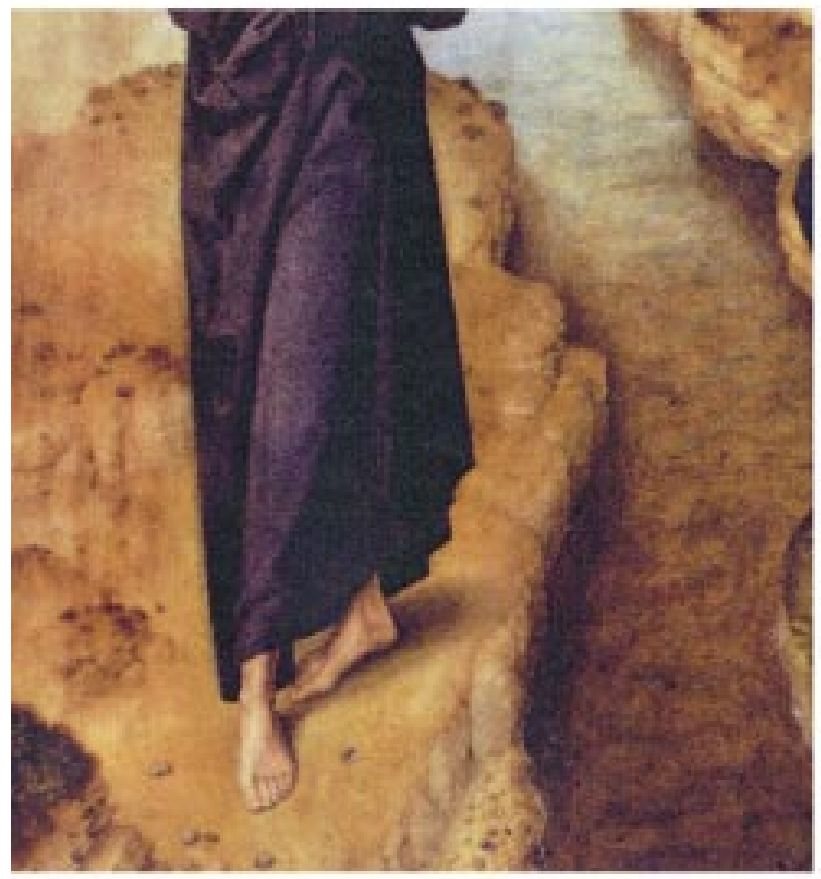

fig 1B

Figure 1 Dirk Bouts. "Ecce Agnus Dei". ${ }^{1}$ Reproduced with permission of Bayerische Staatsgemäldesammlungen, Munich.

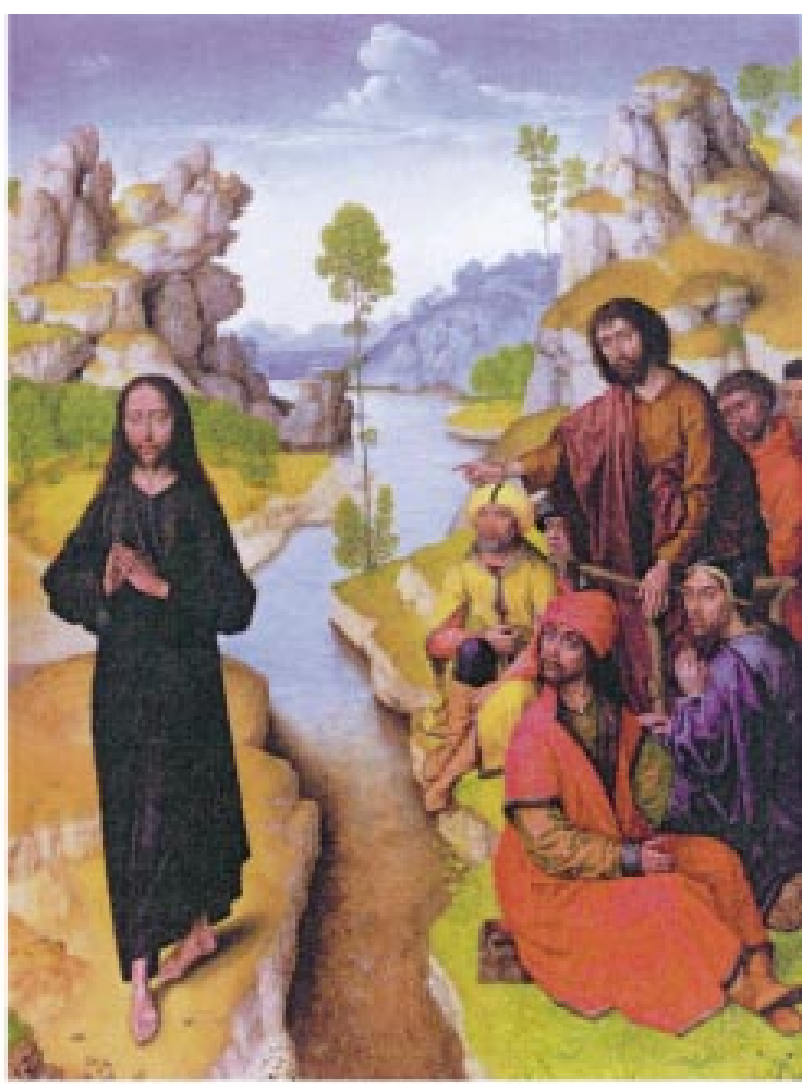

fig $2 \mathrm{~A}$

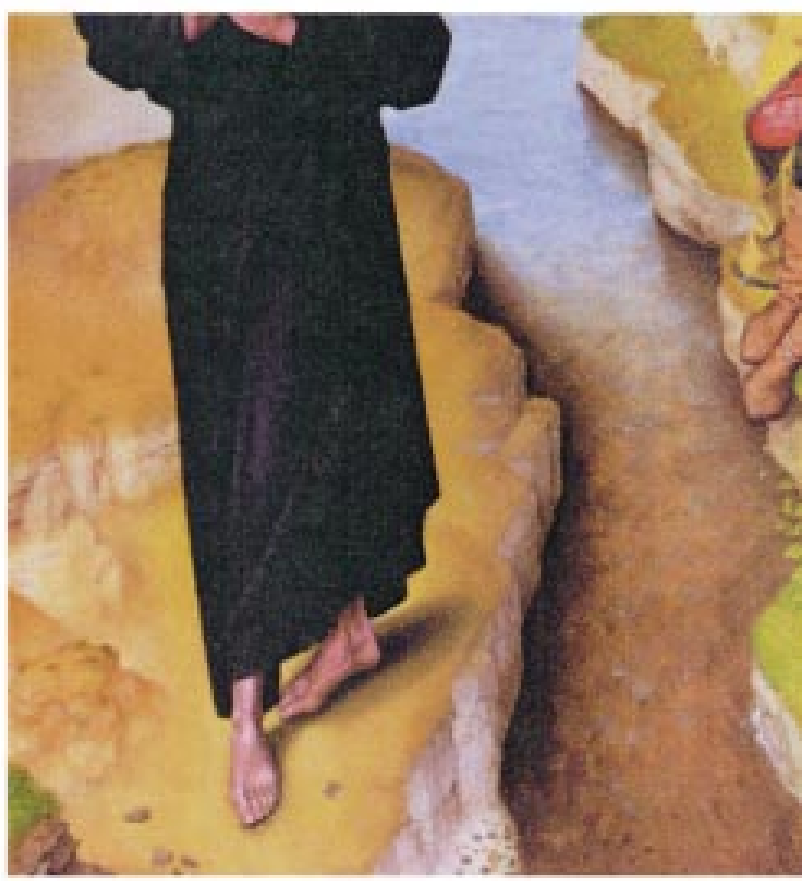

fig 2B

Figure 2 After Dirk Bouts. "St Fohn the Baptist recognises Christ on the bank of the river Fordan." Reproduced with permission of the Staatliche Museen Preussicher Kulturbesitz, Gemäldegalerie, Berlin. 